\title{
Cinara (Hemiptera: Aphidoidea) species distributed in Turkey and their host plants
}

\author{
Türkiye'de dağıım gösteren Cinara (Hemiptera: Aphidoidea) türleri ve konak bitkileri \\ Hayal AKYILDIRIM BEĞEN ${ }^{a^{*}}$; , Gazi GÖRÜR ${ }^{b}$, Özhan ŞENOL ${ }^{b}$ (]) \\ a Health Services Vocational School, Artvin Coruh University, Artvin, Turkey \\ ${ }^{b}$ Department of Biotechnolgy, Faculty of Art and Science, Niğde Ömer Halisdemir University, Niğde, Turkey
}

\begin{abstract}
Article Info
(C)2018 Ali Nihat Gökyiğit Botanical Garden Application and Research Center of Artvin Coruh University.

*Corresponding author:

e-mail: h.akyildirim@artvin.edu.tr ORCID:0000-0003-2028-5827

\section{Article history}

Received: March 12, 2019

Received in revised form: March 29, 2019

Accepted: March 29, 2019

Available online: March 30, 2019
\end{abstract}

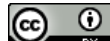

This is an Open Access article under the CC BY license (http://creativecommons.org/licenses /by/4.0/).

Keywords:
Aphid, Cinara, Cupressaceae,
Pinaceae, plant, Turkey.

Anahtar kelimeler:

Afit, Cinara, Cupressaceae, Pinaceae, bitki, Türkiye.

\begin{abstract}
This study has been carried out between 2009 and 2018 in order to determine Cinara species and their host plants distributed in some region of Turkey. Cinara belongs to Eulachnini tribes and Lachninae subfamily, which in the light of the latest molecular studies have turned out to be the basal group for the other aphids. Aphids of the Cinara genus (Hemiptera: Aphidoidea) includes about 200 species in the World and infest lignified parts, branches, trunks, roots and leaves of Pinaceae (especially Pinus, Cedrus, Abies and Picea land Cupressaceae trees. Cinara species were identified according to the host plants where they colonize. Turkey distribution of this genus unknown exactly because of lack of enough studies on aphids. In the earlier studies, only 23 Cinara species were known from Turkey. As a result of these studies, 29 Cinara species collected on different plant species (Pinus spp., Cedrus spp., Juniperus spp., Cupressus spp., Plathyclaudus spp., Picea spp. and Abies nordmanniana) in the areas and 7 of them are new records for Turkey. The number of Cinara species occurring in Turkey has risen to 30 with these studies. Their world and Turkey distribution, host plants and population density were given.
\end{abstract}

Öz

Bu çalışma 2009 - 2018 yılları arasında, Türkiye'nin bazı kısımlarında dağılmış Cinara türlerini ve konak bitki türlerini belirlemek amacıyla yapılmıştır. Cinara cinsi afit türleri Eulachnini tribusu ve Lachninae altfamilyasına ait olup, son yapılan moleküler çalışmalar ile diğer afit türlerinin alt grubunu oluşturduğu belirlenmiştir. Dünya üzerinde yaklaşık 200 tür içerirler ve Pinaceae (özellikle Pinus, Cedrus, Abies ve Picea) ve Cupressaceae ağaçlarının odunlaşmış kısımları, dal gövde ve iğne yaprakları üzerinden beslenirler. Bu türlerin teşhisleri konak olarak kullandıkları bitkilere göre yapılmaktadır. Bu cins ile ilgili daha önce yapılan çalışmalarda Türkiye için 23 türün varlığı belirtilmiş fakat Türkiye dağııımları tam olarak verilmemiştir. Bu çalışma sonucunda, alandan farklı bitki türleri (Pinus spp., Cedrus spp., Juniperus spp., Cupressus spp., Plathyclaudus spp., Picea spp. ve Abies nordmanniana) üzerinden 29 Cinara türü tespit edilmiștir ve bu türlerin 7 'si Türkiye için yeni kayıt olarak verilmiştir. Bu çalışmalar ile Türkiye'deki Cinara cinsine ait afit türü sayısı 30'a yükselmiştir. Türkiye ve Dünya dağılımları, konak bitkileri ve populasyon yoğunlukları verilmiştir.

Citation:

To cite this article: Akyıldırım BeğenH, GörürG, Şenol Ö (2019). Cinara (Hemiptera: Aphidoidea) species distributed in Turkey and their host plants. Turk J Biod 2(1): 24-33.

\section{INTRODUCTION}

Subfamily Lachninae consist of species belonging to Cinara genus that use conifers as a host plant especially Pinaceae and Cupressaceae (Blackman \& Eastop, 2019). Cinara (Aphididae: Lachninae) is one of the largest genera in aphis with about 200 species (Favret, 2019). Cinara belongs to Eulachnini tribes and Lachninae subfamily, which in the light of the latest molecular studies have turned out to be the basal group for the other aphids (Ortiz-Rivas \& Martinez-Torres, 2010). Cinara species originated from Asia about 50 million 
years ago. The ancestors hosted on Angiospermae plants migrated to the conifers and showed the host change (Meseguer et al., 2015). These species are monophyletic species in Aphididae (Heie, 1987; Normark, 2000). Aphis belong to the Cinara genus generally feed on leafy and woody part of Pinacae and Cupressaceae (Pinus, Abies, Larix, Picea and Cedrus spp. (trunks, branches or roots) and might cause permanent damage to the host plant including wrapping and drying (Blackman \& Eastop, 2019). The number of species is still increasing due to expansion of the warm climate species i.e. Cinara tujafilina (Del Guercio) (Durak \& Borowiak-Sobkowiak, 2013). Cinara species have similar morphological and biological characters, any species feed on different host plant can be separated from each other according to small morphological differences according to their identification keys. As genus Cinara is very large group that consist of a lot of species differed from each other only with small morphological features, having complex life cycle and close relationships with their host plants, it is difficult to identify them accurately by performing traditional identification keys based on morphology. Therefore, taxonomic situations and diagnosis are complex (Favret \& Voegtlin, 2004a, 2004b).

The aphid studies carried out in recent years and the aphid fauna of our country has been shown to be represented by approximately 3 families, 141 genera and more than 550 species (Remaudiere et al., 2006; Akyıldırım et al., 2013; Görür et al., 2012; 2014; Şenol et al., 2014; Görür et al., 2018).

The species of Cinara (Lachnidae), which were identified in the study, are found on plant species in the families of Pinaceae and Cupressaceae and these plant species are generally distributed in the Northern Hemisphere. Most of the Cinara species in the world (150 species) have been found in North America and 30 species in Europe and Mediterranean and 25 species in Far East. Turkey distribution of this genus was not sufficiently known because of the limited number of studies related with this group. 23 Cinara species have been listed from Turkey (Remaudiere et al., 2006; Toper Kaygın et al., 2008; Akyürek et al., 2010).

The aim of the paper was to give information about aphid species belonging to Cinara genus and their host plants, distributions and population structures in Turkey.

\section{MATERIAL AND METHOD}

\subsection{Research area}

Research areas are located in different region of Turkey. Studies were carried out from the Eastern Black Sea (Trabzon, Rize, Artvin) between 2009-2010, Niğde in 2010, Istanbul- Princes Islands in 2010 and Inner-West Anatolia (Kütahya, Uşak, Afyonkarahisar) regions between 2012-2014, Eastern Anatolia region (Adıyaman, Şanlıurfa, Malatya) between 2016-2018 (Figure 1). The host plant used by Cinara species distribute densely in Inner-West Anatolia.

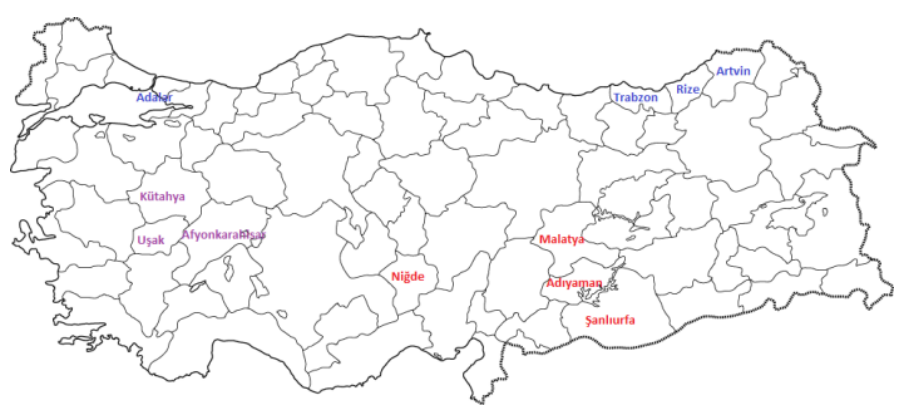

Figure 1. Locations of the study areas.

\subsection{Specimen collection}

Aphid specimens were transferred into ependorf tubes containing $95 \%$ ethanol by means of a soft, fine-tipped brush. The samples were usually made over dense colonies and about 5-10 specimens were taken from a population in an ependorf tube, the label number is written. General information (date, locality, host) of the sample was written. Voucher specimens were deposited in Biotechnology laboratory of Niğde Ömer Halisdemir University.

\subsection{Preparation of specimens}

Samples (indicating each separate collection from different colonies, whether from the same host plant or different host plants) were processed in a laboratory according to the methods of Martin (1983).

\subsection{Morphological studies and identification}

The species were diagnosed according to Blackman and Eastop (2019) and Quednau (1999, 2003) and their taxonomic statuses were checked in accordance with recently evaluated sources and literatures (Favret, 2019; Nieto Nafria, 2019). Approximately 600 colonies were collected from seven different host genera (Pinus spp., Cedrus spp., Picea spp., Abies nordmanniana, Plathyclaudus spp., Cupressus spp., Juniperus spp.) and 
their diagnoses were made using host-specific diagnostic keys. Diagnosis was made with the Olympos BX-53 microscope.

Slides of identified samples were deposited in the Biotechnology Department of Niğde Ömer Halisdemir University. Worldwide distribution, biology and host plants were taken mainly from the previous literature for each newly recorded species.

\section{RESULTS}

As a result of this study, a total of 29 taxa of Cinara genus belonged to Hemiptera were determined from different part of Turkey. These species use seven host plant genera (Table 1). Depending on the plant species collected, dense populations on the branch and on the trunk of the cedar, under the cones and on the needle and on the twigs of Pinus species were determined. Although extensive sampling was carried out from the Eastern Black Sea (Trabzon, Rize, Artvin), Niğde and Inner-West Anatolia (Kütahya, Uşak, Afyonkarahisar) regions, a limited number of sampling was done in the Eastern Anatolia region (Adıyaman, Şanlıurfa, Malatya) and İstanbul-Princes Islands in Turkey.

The dispersion of the plant taxa that were defined in the study area according to the large taxonomical groups is shown in Table 1.

Table 1. The dispersion of taxa into research areas.

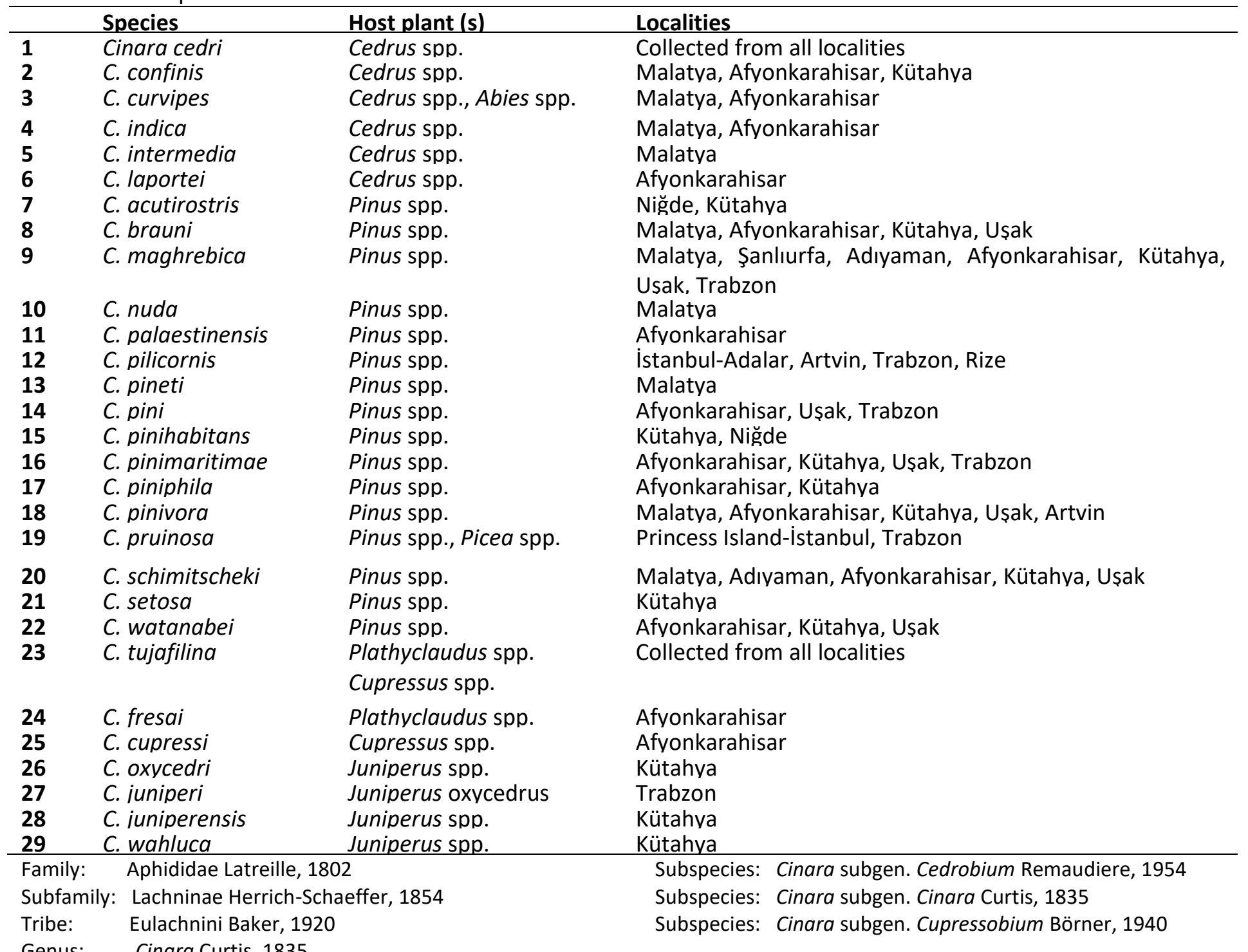




\subsection{Cinara species on Pinus spp. and Picea spp.}

As a result of the sampling and performing diagnostic keys in order to determine the species of genus Cinara that uses Pinus and Picea species as hosts and to determine similarities and differences between species, 16 species belonging to the genus Cinara (Cinara acutirostris, C. brauni, C. maghrebica, C. nuda, C. palaestinensis, C. pilicornis, C. pineti, C. pini, C. pinihabitans, C. pinimaritimae, C. piniphila, C. pinivora, C. pruinosa, C. schimitscheki, C. setosa and C. watanabei) were determined (Table 1 and Figure 2). General characteristics of these species given as follows;

\section{Cinara (Cinara) acutirostris Hille Ris Lambers, 1956;}

Host Plants: Pinus nigra and Pinus pinea

Parts of plant they feed: Bottom of the needle leaf or on the branches

World wide distribution:Palaearctic (Remaudiere et al., 2006; Holman,2009; Blackman \& Eastop, 2019)

Turkey distribution: Konya (Nieto Nafria, 2019)

Collected samples: Sampling over 3 populations on Pinus spp. (Table 1)

Cinara (Cinara) brauni Börner, 1940;

Host Plants: Pinus nigra

Parts of plant they feed: New shoots.

World wide distribution: Palaearctic (Holman, 2009; Blackman \& Eastop, 2019; Nieto Nafria, 2019)

Turkey distribution: Ankara, Bartın, Bursa, Çankırı, stanbul, Konya and Muğla (Toper Kaygın \& Çanakçığlu, 2003; Toper Kaygın et al., 2008; Tuatay, 1999)

Collected samples: Sampling over 24 populations on Pinus spp. (Table 1)

Cinara (Cinara) maghrebica Mimeur, 1934;

Synonyms: Cinara maghrebica subsp. maghrebica Mimeur, 1934; Cinara maghrebica subsp. garganica Binazzi, 1983

Host Plants: Pinus spp. ( $P$. canariensis, $P$. halepensis, $P$. pinaster, P.pinea)

Parts of plant they feed: Dense colonies on young branches

World wide distribution: Palaearctic (Blackman \& Eastop, 2019; Holman 2009)

Turkey distribution:Samsun and Trabzon (Akyürek, 2006; Görür et al., 2009a, 2009b)

Collected samples: Sampling over 39 populations on Pinus spp. (Table 1)

Cinara nuda (Mordvilko, 1895);

Host Plants: Pinus spp.

Parts of plant they feed: Trunk and basal parts of older branches of young trees

World wide distribution: Europe and Kazakhstan (Blackman \& Eastop, 2019)
Turkey distribution: Malatya (Görür et al., 2018)

Collected samples: Sampling over 1 population on Pinus spp. (Table 1)

Cinara (Cinara) palaestinensis Hille Ris Lambers, 1948; Synonyms: Cinara (Cinara) palaestinensis apulica Binazzi, 1983; Cinara (Cinara) palaestinensis palaestinensis Hille Ris Lambers, 1948

Host Plants: Pinus halepensis, P. brutia, $P$. sylvestris

Parts of plant they feed: Dense colonies on new shoots

World wide distribution: Palaearctic (Blackman \& Eastop, 2019; Holman 2009)

Turkey distribution: İstanbul, Muğla, Mersin, Eskişehir, Trabzon, Adana, İçel, Afyonkarahisar (Görür et al., 2014; Toper Kaygın \& Çanakçıoğlu, 2003)

Collected samples: Sampling over 2 populations on Pinus spp. (Table 1)

\section{Cinara (Cinara) pilicornis (Hartig, 1841);}

Synonyms: Aphis abietis Walker, 1848; Lachnus flavus Mordvilko 1894; Lachnus hyalinus Koch, 1856; Lachnus macrocephalus Buckton, 1881; Lachnus pinicola Kaltenbach, 1843

Host Plants: Pinus spp., Picea spp., Tsuga spp.

Parts of plant they feed: Under needle leaves

World wide distribution: Cosmopolit except for Afrika (Holman, 2009)

Turkey distribution: İstanbul, Artvin, Trabzon, Giresun, Ankara, Niğde and Konya (Çanakçığlu, 1975; Tuatay, 1999; Toper Kaygın \& Çanakçioğlu, 2003; Görür, 2004a; Görür, 2004b; Altay \& Uysal, 2005; Blackman \& Eastop, 2019)

Collected samples: Sampling over 2 populations on Pinus spp. (Table 1)

Cinara pineti (Fabricus, 1781);

Synonyms: Lachnus pineti Koch, 1855

Host Plants: Pinus spp.

Parts of plant they feed: Young shoots, branches and under needle leaves

World wide distribution: Neoarctic (Holman, 2009)

Turkey distribution:Malatya (Görür et al., 2018)

Collected samples: Sampling over 1 population on Pinus spp. (Table 1)

\section{Cinara (Cinara) pini (Linnaeus, 1758);}

Synonyms: Cinara nuda auct.nec Mordvilko, 1895; Aphis nuda subsp. pini Börner, 1952; Aphis nudapini DeGeer, 1773; Lachniella oblonga Del Guercio, 1909; Lachnus pineti Hartig, 1839; Cinara (Cinara) polyseta; Lachnus taeniatus Koch, 1856; Lachnus toeniatus Schouteden, 1900; Aphis nuda-pini De Geer, 1773.

Host Plants: Pinus spp. 
Parts of plant they feed: Young shoots, branches and under needle leaves

World wide distribution: Palaearctic (Holman 2009; Blackman \& Eastop, 2019)

Turkey distribution:Bolu-Aladağlar, Antalya, Muğla-Marmaris, İzmir, Çankırı-Ilgaz dağı, Kars-Sarıkamış, Samsun-Alaçam, Çanakkale, Edirne, Kahramanmaraş, Bartın (Tuatay, 1999; Aslan \& Uygun, 2005; Toper Kaygın et al., 2008)

Collected samples: Sampling over 3 populations on Pinus spp. (Table 1)

Cinara (Cinara) pinihabitans (Mordvilko, 1895);

Synonyms: Lachnus taeniatus Koch, 1856; Lachnus toeniatus Schouteden, 1900.

Host Plants:Pinus spp. (Pinus sylvestris and P. mugo var. mughus)

Parts of plant they feed: Shells of 2-8 years thin branches World wide distribution: Palaearctic and Oriental (Holman 2009; Blackman \& Eastop, 2019)

Turkey distribution:Niğde Kütahya (Görür et al., 2014)

Collected samples: Sampling over 3 populations on Pinus spp. (Table 1)

Cinara (Cinara) pinimaritimae (Dufour, 1833);

Synonyms: Cinara excelsae Hille Ris Lambers, 1948; Cinara maritimae Eastop ve Hille Ris Lambers, 1976; Lachnus pineti (Koch, 1855); Aphis pini subsp. maritimae (Dufour, 1833); Lachnus pinicola (Kaltenbach, 1843).

Host Plants: Pinus spp.

Parts of plant they feed: Young shoots and in small groups between the leaves of the needle sheets

World wide distribution: Palaearctic and Neotropical (Holman 2009; Blackman \& Eastop, 2019)

Turkey distribution:Afyonkarahisar, Kütahya, Uşak (Görür et al., 2014)

Collected samples: Sampling over 28 populations on Pinus spp. (Table 1)

Cinara (Cinara) piniphila (Ratzeburg, 1844);

Host Plants: Pinus spp.

Parts of plant they feed: Between needle leaves and shells of branches

World wide distribution: Palaearctic and Oriental (Holman 2009; Blackman \& Eastop, 2019)

Turkey distribution:Afyonkarahisar, Kütahya (Görür et al., 2014)

Collected samples: Sampling over 6 populations on Pinus spp. (Table 1)

Cinara (Cinara) pinivora (Wilson, 1919);

Synonyms: Cinara osborni Tissot, 1944; Cinara osborniana Tissot, 1945.

Host Plants: Pinus spp. (especially Pinus edulis)
Parts of plant they feed: Under cones and on needle leaves World wide distribution: Nearctic (Holman 2009; Blackman \& Eastop, 2019)

Turkey distribution:Afyonkarahisar, Bartın, Kütahya, Uşak (Görür et al., 2014; Toper Kaygın et al., 2008)

Collected samples: Sampling over 21 populations on Pinus spp. (Table 1)

\section{Cinara pruinosa (Hartig, 1841);}

Host Plants: Pinus spp. and Picea spp.

Parts of plant they feed: Woody twigs and base of trunk and on roots

World wide distribution: Palearctic (Holman 2009; Blackman \& Eastop, 2019)

Turkey distribution:Princess Island and Trabzon (Akyıldırım, 2010; Görür et al., 2009a)

Collected samples: Sampling over 2 populations on Picea spp. (Table 1)

\section{Cinara (Cinara) schimitscheki Börner, 1940;}

Synonyms: Cinara kosarowi Tashev, 1962

Host Plants: Pinus spp. (Especially Pinus nigra, P. nigra subsp. pallasiana, $P$. mugo, $P$. pinea, $P$. tabulaeformis, $P$. massoniana and $P$. leucodermis)

Parts of plant they feed: Under cones and on needle leaves

World wide distribution: Palaearctic and Oriental (Holman 2009; Blackman \& Eastop, 2019).

Turkey distribution:Afyonkarahisar, Bartın, Kütahya, Uşak, Niğde (Görür et al., 2014; Toper Kaygın et al., 2008)

Collected samples: Sampling over 45 populations on Pinus spp. (Table 1)

Cinara (Cinara) setosa (Börner, 1950);

Host Plants: Pinus spp. (Pinus mugo and Pinus nigra var. pallasiana)

Parts of plant they feed: Needle leaves

World wide distribution: Palaearctic (Holman 2009; Blackman \& Eastop, 2019)

Turkey distribution:Kütahya (Görür et al., 2014; Şenol et al., 2015)

Collected samples: Sampling over 2 populations on Pinus spp. (Table 1)

\section{Cinara (Cinara) watanabei Inouye, 1970;}

Host Plants: Pinus spp.

Parts of plant they feed: 3-5-year branches of mature trees or in the trunk of young trees

World wide distribution: Palaearctic (Holman 2009; Blackman \& Eastop, 2019)

Turkey distribution:Afyonkarahisar, Kütahya, Uşak (Görür et al., 2014)

Collected samples: Sampling over 34 populations on Pinus

spp. (Table 1) 


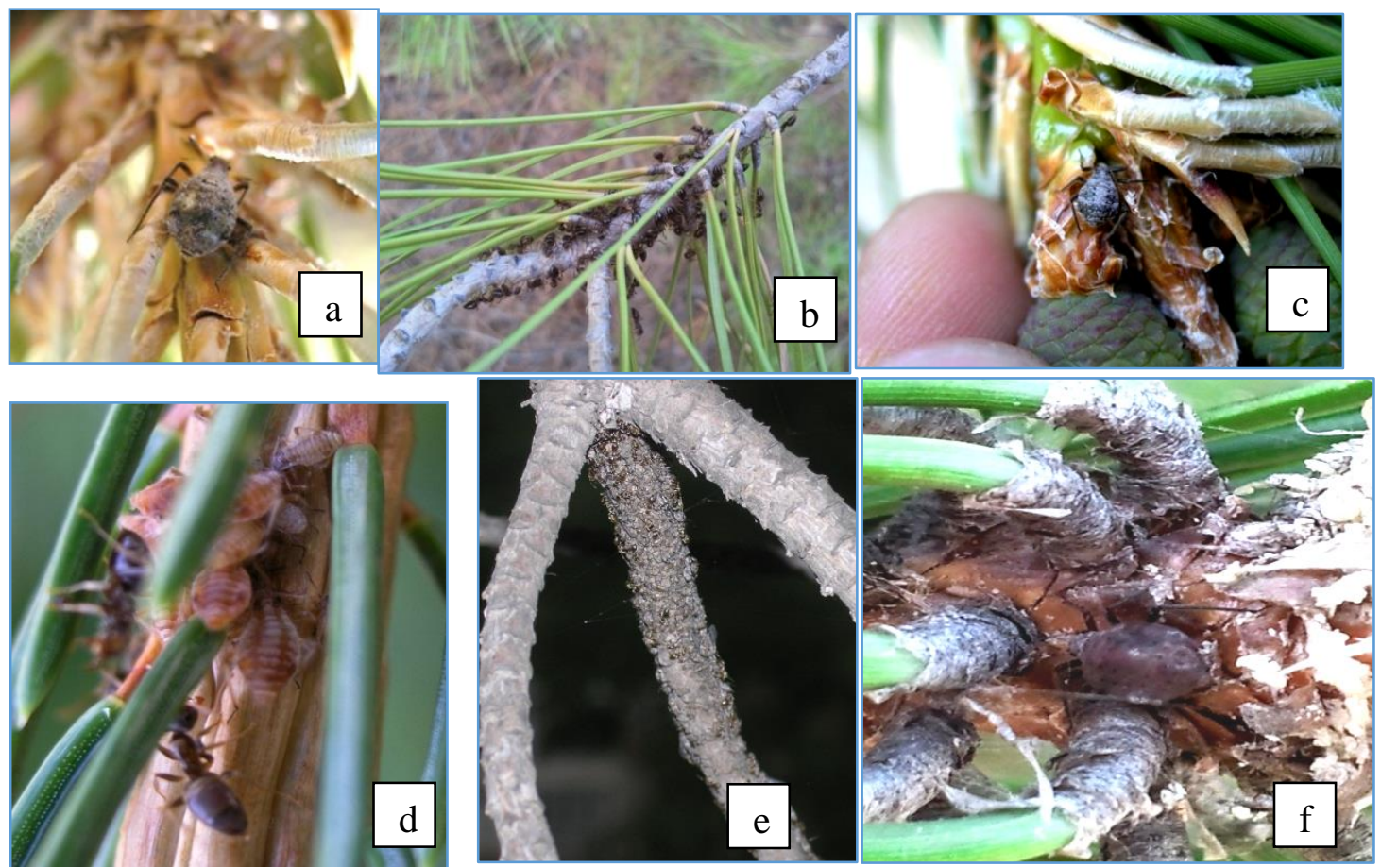

Figure 2. Some important Cinara species on Pinus spp. (a: C. schimitscheki; b: C. maghrebica; c: C. pinivora; d: C. pilicornis; e: C. pini; f: C. pinimaritimae)

\subsection{Cinara species on Cedrus spp. and Abies spp.}

Eight cedar aphid species has been detected on the Earth and six of them (Cinara cedri, C. confinis, $C$. curvipes, $C$. indica, $C$. intermedia, $C$. laportei) have been distributed in Turkey (Blackman \& Eastop, 2019). It was observed that $C$. cedri species was the leading species in terms of number or density (Figure 3 ).

Cinara (Cinara) cedri Mimeur, 1936;

Host Plants: Cedrus spp.

Parts of plant they feed: Shoots and slots of trunk World wide distribution: Palaearctic, Neoarctic and Neotropic (Holman, 2009; Blackman \& Eastop, 2019; Nieto Nafria, 2019) Turkey distribution:Ankara, Antalya, Bartın, Burdur, Eskişehir, Gaziantep, Hatay, İstanbul, Konya, Kastamonu, Samsun, Tekirdağ (Tuatay, 1999; Ünal \& Özcan, 2005; Toper Kaygın et al., 2008)

Collected samples: Sampling over 260 populations on Cedrus spp. (Table 1)

Cinara (Cinara) confinis (Koch, 1856);

Synonyms: Lachnus abieticola Cholodkovsky, 1899; Aphis borealis Curtis 1828; Lachniella cilicica Del Guercio, 1909; Cinara ciliciea Ghosh, 1982; Lachnus lasiocarpae Gillette ve Palmer, 1930; Aphis polaris Curtis 1828; Lachnus vanduzei Swain, 1919; Todolachnus abieticolabulgarica Pintera, 1959; Lachniella cilicica cecconii Del Guercio, 1909.

Host Plants: Cedrus spp. and Abies spp.
Parts of plant they feed: Shoots and slots of trunk World wide distribution: Palaearctic and Oriental (Holman, 2009; Blackman \& Eastop, 2019; Nieto Nafria, 2019)

Turkey distribution:Ankara, Artvin, Bartın, Bolu, Bursa and Çankırı (Toper Kaygın et al., 2008; Tuatay, 1999; Önder et al., 2011)

Collected samples: Sampling over 6 populations on Cedrus spp. (Table 1)

\section{Cinara (Cinara) curvipes (Patch, 1912);}

Host Plants: Abies spp., Cedrus spp. and Picea spp., rarely Pinus spp.

Parts of plant they feed: Shoots and branches

World wide distribution: Palearctic (Holman, 2009; Blackman \& Eastop, 2019; Nieto Nafria, 2019)

Turkey distribution:Afyonkarahisar, Bartın, Kütahya (Görür et al., 2014; Görür et al., 2015)

Collected samples: Sampling over 2 populations on Abies spp. (Table 1)

Cinara (Cinara) indica Verma, 1970;

Synonyms: Cinara indica Verma 1969

Host Plants: Cedrus spp.

Parts of plant they feed: Trunk

World wide distribution: Palearctic (Holman, 2009; Blackman \& Eastop, 2019)

Turkey distribution:Afyonkarahisar, Malatya (Görür et al., 2014; Görür et al., 2018)

Collected samples: Sampling over 2 populations on Cedrus spp. (Table 1) 
Cinara (Cinara) intermedia (Pasek, 1954);

Host Plants: Pinus spp. and Cedrus spp.

Parts of plant they feed: Bark of trunk

World wide distribution: Europe (Blackman \& Eastop, 2019)

Turkey distribution:Malatya (Görür et al., 2018)

Collected samples: Sampling over 1 population on Cedrus spp. (Table 1)

Cinara (Cedrobium) laportei (Remaudière, 1954);

Host Plants:Cedrus spp.

Parts of plant they feed: Lower branches, shoots and young branches

World wide distribution: Palearctic and Ethiopian (Fabre \& Chalon, 2005)

Turkey distribution: Antalya, Burdur, Muğla and Samsun (Akyürek, 2006; Nieto Nafria, 2019)

Collected samples: Sampling over 4 populations on Cedrus spp. (Table 1)

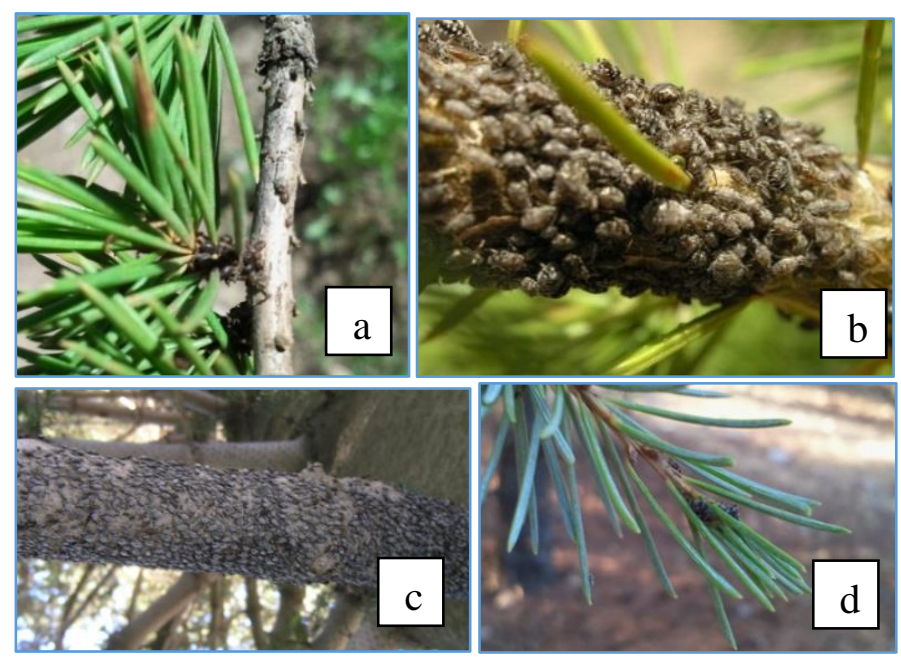

Figure 3. Some important Cinara species on Cedrus spp. (a: C. confinis; b: C. cedri; c: C. curvipes; d: C. indica)

\subsection{Cinara species on Plathyclaudus spp., Juniperus spp.and Cupressus spp.}

Within the scope of this study, 7 species (C. tujafilina, $C$. fresai, C. cupressi, C. oxycedri, C.juniperensis, C. juniperi and $C$. wahluca) belonging to the genus Cinara were identified from Cupressaceae plants (Cupressus spp., Plathycladus spp., Juniperus spp.) from different region of Turkey (Figure 4).

Cinara (Cupressobium) juniperi De Geer, 1773;

Host Plants: Juniperus spp.

Parts of plant they feed: Between needle leaves and young end shoots
World wide distribution: Nearctic, North Africa (Holman, 2009; Blackman \& Eastop, 2019)

Turkey distribution:Trabzon (Görür et al., 2009a)

Collected samples: Sampling over 1 population on Juniperus spp. (Table 1)

Cinara (Cinara) juniperensis (Gillette ve Palmer, 1925);

Host Plants: Juniperus spp.

Parts of plant they feed: Between needle leaves and young end shoots

World wide distribution: Nearctic (Holman, 2009; Blackman \& Eastop, 2019)

Turkey distribution:Kütahya (Görür et al., 2014)

Collected samples: Sampling over 1 population on Juniperus spp. (Table 1)

Cinara (Cinara) wahluca Hottes, 1952;

Host Plants: Juniperus spp.

Parts of plant they feed: Bottom of the needles leaves, slits of the branches

World wide distribution: Nearctic (Blackman \& Eastop, 2019)

Turkey distribution: Samsun (Akyürek et al. 2010)

Collected samples: Sampling over 1 population on Juniperus spp. (Table 1)

Cinara (Cupressobium) cupressi (Buckton, 1881);

Synonyms: Cinara canadensis Hottes ve Bradley, 1953; Cinara cupressivora Watson ve Voegtlin, 1999; Lachnus sabinae Gillette ve Palmer, 1924; Lachniella tujae Del Guercio, 1909; Lachniella juniperi signata Del Guercio, 1909.

Host Plants: Plathyclaudus orientalis, Cupressus spp. and Juniperus spp.

Parts of plant they feed on: Thin branches and young shoots World wide distribution: Palearctic and Oriental (Holman, 2009; Blackman \& Eastop, 2019)

Turkey distribution: Bartın, Bolu and Kahramanmaraş (Aslan \& Uygun, 2005; Toper Kaygın et al., 2008)

Collected samples: Sampling over 2 populations on Cupressus spp. (Table 1)

Cinara (Cupressobium) fresai Blanchard, 1939;

Synonyms: Cinara (Cupressobium) bresai Toper Kaygın and Çanakçıoglu, 2003; Cupressobiummaui Bradley 1965; Cinara wacasassae Tissot, 1944.

Host Plants: Cupressus spp., Plathycladus spp., and Juniperus spp., rarely Cryptomeria spp.

Parts of plant they feed: Shoots, needle leaves and branches World wide distribution: Nearctic, Australia, Palearctic (Holman, 2009; Blackman \& Eastop, 2019)

Turkey distribution:Adana and Ankara (Tuatay, 1999; Toros et al., 2002)

Collected samples: Sampling over 1 population on Plathyclaudus spp. (Table 1) 
Cinara (Cupressobium) oxycedri Binazzi, 1996;

Host Plants: Juniperus oxycedrus and J. oxycedrus subsp. macrocarpa

Parts of plant they feed: Shoots, needle leaves and branches World wide distribution: Palearktic (Holman 2009; Blackman \& Eastop, 2019)

Turkey distribution: Kütahya (Görür et al., 2014)

Collected samples: Sampling over 1 population on Juniperus spp. (Table 1)

Cinara (Cupressobium) tujafilina (Del Guercio, 1909);

Synonyms: Lachnus biotae (van der Goot, 1917); Dilachnus callitris Froggatt, 1927; Cinaropsis cupresi Gomez-Menor, 1962; Lachnusgreeni Schouteden 1905; Cupressobium mediterraneum Narzikulov, 1963; Lachnus sabinae Nevsky, 1929; Lachniella thujafolia Theobald, 1914; Cinara winokae Eastop, 1972; Cinara winonkae Hottes, 1934; Cinara winonokae Zhang, Zhang \& Zhong, 1993.

Host Plants: Callitris spp., Chamaecypari spp., Cupressus spp., Juniperus spp. (except for communis) Plathycladus spp. and Widdringtoria spp.

Parts of plant they feed: Leafy branches, the lower surfaces of the branches and near trunk

World wide distribution: Australia, Palaearctic and Neotropical (Holman 2009; Blackman \& Eastop, 2019)

Turkey distribution:Ankara, Konya, Malatya, Eskişehir, İstanbul, Artvin, Adana and Niğde (Çanakçıoğlu, 1975; Düzgüneş et al., 1982; Tuatay, 1999; Toros et al., 2002; Görür, 2004b)

Collected samples: Sampling over 42 populations on Plathyclaudus spp. and Cupressus spp. (Table 1)

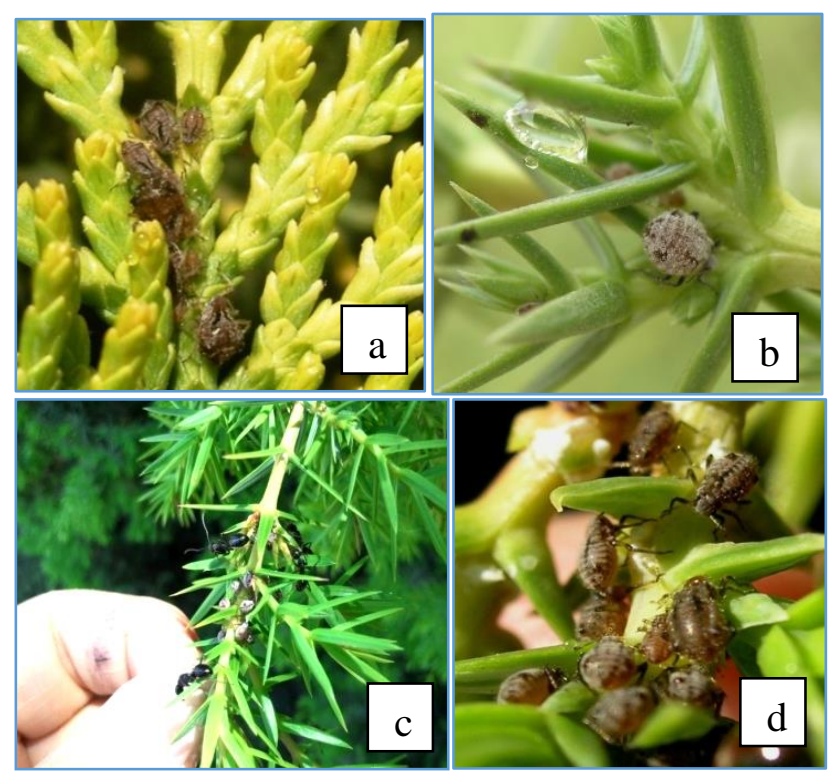

Figure 4. Some important Cinara species on Plathyclaudus sp. and Juniperus oxycedrus (a: $C$. tujafilina; b: C. juniperensis; c: C. cupressi; d: C. oxycedri)

\section{CONCLUSIONS AND COMMENTS}

Aphids are highly host specific insect and therefore host plant features play an important role on aphids. Turkey has higher plant biodiversity richness and rate of endemic plant is about $34.4 \%$. Gymnospermae richness of our forest is more than Angiospermae (54\%) and $50.8 \%$ of this plant species are belonging to Pinaceae and $3.6 \%$ are to Cupressaceae families (Seçmen et al., 1998). This Gymnospermae species were found in the studied areas and Cinara samples were collected from those which were grown as natural and exotic. Especially in North Hemisphere, Cinara aphids distributed densely and use conifers as host plant (Blackman \& Eastop, 2019).

Presented results are the first detailed scientific study dealing with Cinara genus in Turkey. The total number of Cinara aphid species recorded in Turkey is 29. Despite that, it can be considered that this number is much lower compared with records in neighbouring countries (North America has 150 species, Poland 27 species, Italy 26 species) as Turkey has particular geographical, agricultural, climatic and floristic characteristics (Durak et al., 2008).

In these studies, the Cinara aphid species distributed in Turkey and host plants were tried to be emphasized. As a result of study, 29 aphid species and 7 plant genera belonging to Pinaceae and Cupressaceaae were determined.

Cinara species infest the same host and only body colour and sheen (some morphological characters) differentiate them from each other. This creates serious identification problems for both species, particularly when they occur in mixed colonies and are often wrongly classified (Heie, 2015). Host plants and localities are considered as the main ecological factor involved in the speciation process of this phytophagous insects. They exhibit a diversity of ecological features that make them good models to explore the importance of ecological specialisation in the diversification of aphids. Most species feed on a single or a few species of conifers, while others are less discriminatory, feeding on several species within a genus (Favret \& Voegtlin, 2004a, 2004b).

This data illustrates how neglected is the research areas in terms of faunistic research on Cinara aphids. Further 
studies should definitely reveal much higher number of Cinara aphid taxa and different host plant taxon for Turkey.

\section{ACKNOWLEDGEMENTS}

The authors thank to the Scientific and Technological Research Council of Turkey (TÜBITAK; Project Numbers $115 Z 325,214 Z 016,107 T 450)$ for supporting this study.

\section{REFERENCES}

Akyıldırım H (2010). İstanbul illi Büyük Ada îlçesi Afit (Hemiptera: Aphidoiea) Faunasinin Belirlenmesi. MSc, Niğde Ömer Halisdemir Üniversitesi, Fen Bilimleri Enstitüsü, Niğde, Turkey.

Akyıldırım H, Şenol Ö, Görür G, Demirtaş E (2013). Evaluation of the zoogeographical contents of Turkey aphid (Hemiptera: Aphidoidae) fauna and invasive component. Biyoloji Bilimleri Araştırma Dergisi 6(1), 44-48.

Akyürek B (2006). Ondokuz Mayıs Üniversitesi Kurupelit Kampüs alanı afit (Homoptera: Aphididae) faunasının belirlenmesi. MSc, Ondokuz Mayıs Üniversitesi, Fen Bilimleri Enstitüsü, Samsun, Turkey.

Akyürek B, Zeybekoğlu Ü, Görür G (2010). New records of aphid species (Hemiptera: Aphidoidea) for Turkish fauna from Samsun province. Turkish Journal of Zoology 34: 421-424.

Altay H, Uysal M (2005). Selçuk Üniversitesi Alaeddin Keykubat Kampüs alanında bulunan yaprakbiti (Homoptera: Aphidoidea) türleri. S. Ü. Ziraat Fakültesi Dergisi 19(37): 92- 99.

Aslan MM, Uygun N (2005). Aphids (Homoptera: Aphididae) of Kahramanmaraş Province, Turkey. Turkish Journal of Zoology 29: 201-209.

Blackman RL, Eastop VF (2019). Aphids of the world's plants. An online identification and information guide. http://www.aphidsonworldsplants.info. Downloaded on 28 February 2019.

Çanakçıŏlu H (1975). The Aphidoidea of Turkey. İstanbul: Istanbul University Faculty of Forestry Publication.

Durak R, Sadowska-Woda I, Machordom A, Borowiak-Sobkowiak B (2008). Biological and genetic studies of Polish population of Cinara tujafilina. Bulletin of Insectology 61(1):159-160.

Durak R, Borowiak-Sobkowiak B (2013). Influence of temperature on the biological parameters of the anholocyclic species Cinara tujafilina (Hemiptera: Aphidoidea). Central European Journal of Biology 8: 570-577.

Düzgüneş Z, Toros S, Kılınçer N, Kovancı K (1982). Ankara ilinde bulunan Aphidoidea türlerinin parazit ve predatörlerinin tesbiti. Ankara: Tarım ve Orman Bakanlığı Zirai Mücadele ve Karantina Genel Müdürlüğü Yayınları.

Fabre JP, Chalon A (2005). Multiplication of an ecotype of the aphid Cedrobium laportei (Homoptera Lachnidae) on various provenances of the genus Cedrus pp. 123-138. In: Lieutier E, Ghaioule D (Eds), Entomological Research in Mediterranean forest ecosystems, INRA Editions.

Favret C, Voegtlin DJ (2004a). Speciation by host-switching in pinyon Cinara (Insecta: Hemiptera: Aphididae). Molecular Phylogenetics and Evolution 32:139-151.

Favret C, Voegtlin DJ (2004b). A revision of the Cinara species (Hemiptera: Aphididae) of the United States pinyon pines. Annals of the Entomological Society of America 97(6): 1165-1197.
Favret C (2019). Aphid Species File 5.0/5.0. http://aphid.speciesfile.org. Downloaded on 22 February 2019.

Heie OE (1987). Taxonomy, intraspecific variation and geographical distribution of some species of Nasonovia. In: Holman, J., Pelikan, J., Dixon, A.F.G., Weismann, L. (Eds). Population Structure, Genetics and Taxonomy of Aphids and Thysanoptera. SPB Academic Publishing, The Hague, 293-313.

Heie OE (2015). A theory about the evolutionary history of Lachnidae and comments on the results of some molecular phylogenetic studies of aphids (Hemiptera: Aphidoidea). Polish Journal of Entomology 84 (4): 275-287.

Holman J (2009). Host plant catalog of aphids, Palearctic Region. Branisovska: Springer, $1216 p$.

Görür G (2004a). Aphid (Insecta: Homoptera: Aphidoidea) Species of Nigde province of Turkey. Niğde: Nigde University Publishment.

Görür G (2004b). Aphid (Homoptera: Aphididae) species on pome fruit trees in Niğde province of Turkey. Turkish Journal of Entomology 28(1): 21-26.

Görür G, Zeybekoğlu Ü, Akyürek B, Işık M, Akyıldırım H (2009a). Trabzon, Rize ve Artvin illerinin afit (Homoptera: Aphididae) faunasının belirlenmesi, Proje No: Tubitak 107T450, 205p.

Görür G, Işık M, Akyürek B, Zeybekoğlu Ü (2009b). New records of Aphidoidea from Turkey. Journal of Entomological Research Society 11: 1-5.

Görür G, Akyildirim H, Olcabey G, Akyurek B (2012). The Aphid Fauna of Turkey: An Updated Checklist. Archives of Biological Science Belgrade 64(2): 675-692.

Görür G, Şenol Ö, Akyıldırım H, Demirtaş E (2014). İç Batı Anadolu Bölümü afit (Homoptera: Aphididae) faunasının belirlenmesi. (TUBITAK Proje No: 111T866), Ankara, 223p.

Görür G, Toper Kaygin A, Şenol Ö, Akyildirim Beğen H (2015). Cinara curvipes (Patch, 1912) (Hemiptera; Aphididae) as new aphid species for Turkish aphidofauna. Artvin Coruh University Journal of Forestry Faculty 16: 37-39.

Görür G, Şenol Ö, Parmaksız D (2018). Adıyaman Malatya ve Şanlıurfa illeri Afit Hemiptera Aphidoidea Faunasının Belirlenmesi. (TUBITAK Proje No: 115Z325), Ankara, 263p.

Martin JH (1983). The identification of common aphid pests of tropical agriculture. Tropical Pest Management 29: 395-411.

Meseguer AS, Coeur d'acier A, Genson G, Jousselin E (2015). Unravelling the historical biogeography and diversification dynamics of a highly diverse conifer-feeding aphid genus. Journal of Biogeography 42: 1482-1492.

Nieto Nafria J (2019). Fauna Europaea. Available from: www.faunaeur.org. Downloaded on 24 January 2017.

Normark BB (2000) Molecular systematics and evolution of the aphid family Lachnidae. Molecular Phylogenetics and Evolution 14: 131140

Ortiz-Rivas B, Martinez-Torres D (2010). Combination of molecular data support the existence of three main lineages in the phylogeny of aphids (Hemiptera: Aphididae) and the basal position of the subfamily Lachninae. Molecular Phylogenetics and Evolution 55: 305-317.

Önder F, Tezcan S, Karsavuran Y, Zeybekoğlu Ü (2011). The Cicadomorpha, Fulgoromorpha and Sternorrhyncha (Insecta: Hemiptera), Catalog of Turkey. İzmir: Ege University Plant Protection Publications, 168p.

Quednau FW (1999). Atlas of the Drepanosiphine Aphids of the World. Part1: PanaphidiniOestlund, 1922-Myzocallidina Börner, 
1942 (1930) (Hemiptera: Aphididae: Calaphidinae), Vol: 31(1): Quebec: The American Entomological Institute.

Quednau FW (2003). Atlas of the Drepanosphine Aphids of the World. Part2: Panaphidina Qestlund, 1923-Panaphidina Qestlund, 1923 (Hemiptera: Aphididae: Calaphidinae). Vol: 72. Qubec: The American Entomological Institute.

Remaudière G, Toros S, Özdemir I (2006). New contribution to the aphid fauna of Turkey (Hemiptera: Aphidoidea). Revue française d'Entomologie 28(2): 75-96.

Seçmen Ö, GemicY, Gök G, Leblebici E (1998). Tohumlu Bitkiler Sistematiği. İzmir: Ege Üniversitesi Yayınevi, 296p.

Şenol O, Akyildirim H, Görür G, Demirtas E (2014). New Entry for the Turkey Aphidofauna [Hemiptera: Aphidoidea]. Acta Zoologica Bulgarica 66(1): 133-136.

Şenol, Ö, Beğen, H, Görür, G, Demirtaş, E. (2015). New additions and invasive aphids for Turkey's aphidofauna (Hemiptera: Aphidoidea). Turkish Journal of Zoology 39(1): 39-45. DOI: 10.3906/zoo-1308-12.
Toper Kaygın A, Çanakçıoğlu H (2003). Contributions to the knowledge of conifer aphid fauna in Turkey and their zoogeographical distribution. Journal of Pest Science 76(2): 5056.

Toper Kaygın A, Görür G, Çota F (2008). Contribution to the aphid (Homoptera: Aphididae) species damaging on woody plants in Bartin, Türkiye. International Journal of Natural and Engineering Sciences 2(1): 83-86.

Toros S, Uygun N, Ulusoy R, Satar S, Özdemir I (2002). Doğu Akdeniz Bölgesi Aphidoidea türleri. Ankara: T.C. Tarım ve Köy işleri Bakanlığı Yayınları, 108p.

Tuatay N (1999). Türkiye yaprak bitleri (Homoptera: Aphididae) V. Chaitophinae, Lachninae ve Thelaxinae. Bitki Koruma Bülteni 39(1-2): 1-21.

Ünal S, Özcan E (2005). Kastamonu yöresi Aphididae (Homoptera) Türleri. Süleyman Demirel Üniversitesi Orman Fakültesi Dergisi 1: 76-83. 